\title{
PENGEMBANGAN MODUL BERBASIS KECAKAPAN HIDUP PADA PELAJARAN MATEMATIKA SEKOLAH DASAR
}

\author{
Afib Rulyansah $^{1}$, Mardiyatus Sholihati ${ }^{2}$ \\ ${ }^{1,2}$ Universitas Panca Marga Probolinggo \\ afibrulyansah@upm.ac.id ${ }^{1}$, mardiyatus28@gmail.com ${ }^{2}$
}

\begin{abstract}
ABSTRAK
Prestasi belajar siswa kelas VI SDN Curahsawo dalam materi Debit rendah karena siswa dituntut mempelajari materi yang tidak sesuai dengan karakter siswa dan hanya menggunakan satu bahan ajar yang menekankan pada aspek kognitif. Pengembangan modul berbasis kecakapan hidup ini disesuaikan dengan karakter siswa dan memperhatikan keseimbangan antara aspek kognitif, afektif, dan psikomotorik serta membekali siswa dengan pendidikan kecakapan hidup. Tujuan penelitian ini adalah menghasilkan modul berbasis kecakapan hidup yang valid, praktis, menarik, efektif, serta dapat meningkatkan prestasi siswa kelas VI dari 52\% menjadi minimal $70 \%$. Penelitian ini mengadaptasi model pengembangan Borg \& Gall. Tahap pengembangan ini adalah studi pendahuluan, perencanaan, desain produk, validasi modul, uji coba lingkup kecil, uji coba lingkup besar, revisi modul, dan produk akhir. Hasil validasi ahli materi mencapai $87,5 \%$ dan hasil validasi ahli media mencapai $96,8 \%$. Hasil rata-rata angket kepraktisan berpersentase $88,35 \%$ dan hasil angket kemenarikan siswa berpersentase 94,1\% dalam uji coba lingkup kecil. Sementara untuk uji coba lingkup besar, tingkat kepraktisan modul mencapai 89,5\%, tingkat kemenarikan modul mencapai $92,5 \%$, dan hasil evaluasi belajar siswa menunjukkan $83,3 \%$ tuntas belajar atau $31,3 \%$ lebih tinggi dibandingkan pretest yaitu 52\%. Berdasarkan hasil tersebut, modul berbasis kecakapan hidup telah valid, praktis, menarik, dan efektif digunakan dalam pembelajaran Matematika kelas VI.
\end{abstract}

Kata kunci: modul, kecakapan hidup, debit.

\begin{abstract}
Student learning achievement of the sixth grade students of SDN Curahsawo in the Debit material is very low because students are required to learn material that is not in accordance with the character of students and only uses one teaching material that emphasizes cognitive aspects. The development of life skills-based modules is tailored to the students' character and takes into account the balance between cognitive, affective, and psychomotor aspects as well as equipping students with life skills education. The aim of the research is to produce a valid, practical, interesting, effective life skills-based module, and can improve the performance of sixth grade students from $50 \%$ to more than $70 \%$. The development began with a preliminary study, followed by planning, product design, module validation, small-scale trials, large-scale trials, modules' revision, and final products. The results of the material expert validation reached $87.5 \%$ and the results of media expert validation reached $96.8 \%$. The results of the average practicality questionnaire reached $88.35 \%$ and the results of the student attractiveness questionnaire reached $94.1 \%$ in the small-scale trials. The module's practicality level reached $89.5 \%$, the module's attractiveness level reached $92.5 \%$, and the $83.3 \%$ of students was achieve or $31,3 \%$ higher than pretest $(52 \%)$.
\end{abstract}

Keywords: module, life skills, debit.

\section{PENDAHULUAN}

Salahuddin (2011) menyatakan bahwa tujuan pendidikan manusia yaitu mengarahkan manusia pada pembentukan pola kehidupan yang mandiri dengan 
moralitas yang tinggi dan universal. Dengan kata lain, salah satu tujuan pendidikan adalah life skill education. Pendidikan kecakapan hidup (life skill education) adalah pendidikan yang mengembangkan kemampuan belajar siswa, meminimalisir mindset dan tingkah laku yang kurang tepat, memahami kemampuan/bakat diri agar mampu dikembangkan dan diterapkan pada kehidupan sehari-hari, dan mampu menyelesaikan persoalan kehidupan secara kreatif (Hindun, 2005).

Secara umum kecakapan hidup dibagi menjadi dua, yaitu kecakapan hidup bersifat umum (General Life Skill) dan kecakapan hidup bersifat spesifik (Specific Life Skill) (Supriatna, 2007). Kecakapan hidup bersifat umum adalah kecakapan yang harus dimiliki oleh setiap manusia yang terdiri atas kecakapan personal (personal skill) dan kecakapan sosial (social skill). Kecakapan Personal mencakup kesadaran diri atau memahami diri atau potensi diri, serta kecakapan berpikir rasional. Kecakapan sosial atau kecakapan antar pribadi (interpersonal skill) meliputi kecakapan berkomunikasi dengan empati dan kecakapan bekerja-sama (collaboration skill). Kecakapan hidup spesifik adalah kecakapan yang diperlukan seseorang untuk menghadapi problema bidang khusus seperti pekerjan/kegiatan dan atau keadaan tertentu, yang terdiri atas kecakapan akademik dan vokasional. Kecakapan akademik mencakup antara lain kecakapan mengidentifikasi variabel dan menjelaskan hubungannya dengan suatu fenomena tertentu, merumuskan hipotesis terhadap suatu rangkaian kejadian, serta merancang dan melaksanakan penelitian untuk membuktikan suatu gagasan atau keingintahuan. Kecakapan vokasional terkait dengan bidang pekerjaan atau kegiatan tertentu yang terdapat di masyarakat dan lebih memerlukan keterampilan motorik.

Yasin (2010) menyebutkan tugas guru adalah untuk melakukan pengembangan yang mendukung tercapainya tujuan pendidikan nasional. Guru harus mampu melakukan pengembangan untuk mengukur kompetensi pedagogik yang dimiliki. Kompetensi pedagogik adalah keterampilan pendidikan untuk memahami karakter pebelajar, menyusun perencanaan dan menerapkannya, melakukan evaluasi belajar, dan mengembangkan potensi yang dimiliki siswa. Melalui kompetensi ini, guru dapat melakukan pengembangan yang disesuaikan 
dengan karakteristik, latar belakang sosial, ekonomi, budaya, geografis, serta pengetahuan awal yang dimiliki siswa.

Kondisi yang saat ini terjadi adalah siswa kesulitan memahami materi pelajaran karena mereka dituntut untuk mempelajari materi yang tidak sesuai dengan latar belakang dan karakter lingkungan sosial budayanya. Akibatnya, prestasi belajar siswa rendah. Selain itu, sebagian besar guru hanya berpedoman pada satu bahan ajar untuk menunjang pembelajaran di kelas. Padahal, ada banyak bahan ajar yang dapat menjadi acuan bagi guru untuk memberikan materi sehingga kegiatan belajar mengajar tidak monoton. Kondisi lain yang ada di lapangan yaitu pemilihan bahan ajar yang kurang tepat oleh guru. Sebagian besar bahan ajar yang dipilih guru hanya menekankan pada aspek kognitif dengan proses-proses abstrak yang hanya dapat dipahami oleh orang dewasa. Sementara permasalahan yang akan dihadapi siswa nanti bermacam-macam, bukan hanya yang berkaitan dengan akademik saja. Siswa harus dilatih untuk dapat menyelesaikan segala permasalahan mulai dari hal-hal yang kecil, khususnya yang berkaitan langsung dengan pembelajaran.

Lebih lanjut Majid (2009) mengemukakan bahwa kecerdasan siswa harus dikembangkan berdampingan dengan kemantapan keimanan dan ketakwaan agar tetap dalam kepatuhan pada pencipta. Budi pekerti luhur juga harus ditanamkan untuk pengembangan pengetahuan dan keterampilan agar siswa memiliki kecerdasan dan akhlak baik yang berimbang. Hal lain yang memerlukan perhatian baik wali murid maupun pendidik agar pembelajaran dapat diarahkan pada pembentukan kemampuan siswa agar dapat bermanfaat bagi diri sendiri dan orang lain melalui keterampilan. Oleh sebab itu diperlukan suatu pengembangan yang dapat mewadahi aspek kognitif, afektif, dan psikomotor siswa.

Dari beberapa uraian tersebut, maka dilakukan pengembangan modul berbasis kecakapan hidup khusus untuk pelajaran Matematika materi Debit agar siswa lebih memahami materi Debit yang dikemas dengan memperhatikan latar belakang siswa dan memperhatikan keseimbangan antara ranah kognitif, afektif, dan psikomotor, serta melatih siswa untuk belajar secara mandiri tanpa tergantung pada pertolongan pendidik. Oleh karena itu, disusun penelitian berjudul "Pengembangan Modul Berbasis Kecakapan Hidup pada Pelajaran Matematika 
Sekolah Dasar". Modul ini diharapkan dapat menjadi media berlatih siswa untuk mengembangkan kecakapan hidup baik yang bersifat umum (kecakapan personal dan kecakapan sosial) dan spesifik (kecakapan akademik dan vokasional).

Tujuan riset ini adalah menciptakan produk berupa modul berbasis kecakapan hidup yang memiliki tingkat kevalidan, kepraktisan, kemenarikan, dan keefektifan serta dapat meningkatkan prestasi siswa kelas VI pada materi Debit .

\section{METODE PENELITIAN}

Jenis riset ini adalah penelitian pengembangan atau Research and Development (R\&D). Menurut Sukmadinata (2010), R\&D adalah prosedur pengembangan produk baru sama sekali atau penyempurnaan produk yang telah ada dan dapat dipertanggungjawabkan. Borg \& Gall (1983) menyatakan bahwa R\&D adalah proses pengembangan dan validasi produk.

Penelitian dan pengembangan ini mengadaptasi sepuluh tahapan model Borg \& Gall yaitu: (1) penelitian dan pengumpulan data (research and information collecting), (2) perencanaan (planning), (3) pengembangan awal draf produk (develop preliminary form of the product), (4) uji coba lapangan awal (preliminary field testing), (5) revisi hasil uji coba lapangan awal (main product revision), (6) uji coba lapangan (main field testing), (7) penyempurnaan hasil uji coba lapangan (operational product revision), (8) uji pelaksanaan lapangan (operational field testing), (9) penyempurnaan produk akhir (final product revision), (10) diseminasi dan distribusi (dissemination and distribution). Dari model Borg \& Gall tersebut kemudian dimodifikasi tanpa menghilangkan esensi dasar model pengembangan tersebut. Adapun dasar modifikasi model pengembangan Borg \& Gall adalah penelitian yang dilakukan hanya terbatas pada satu lembaga yaitu SD Negeri Curahsawo Kecamatan Gending Kabupaten Probolinggo, satu tingkatan kelas yaitu kelas VI, satu rombel, serta pertimbangan waktu yang diperkirakan tidak memungkinkan apabila mengembangkan sepuluh langkah pengembangan menurut Borg \& Gall. Oleh karena beberapa hal tersebut maka dilakukan modifikasi model pengembangan Borg \& Gall. 


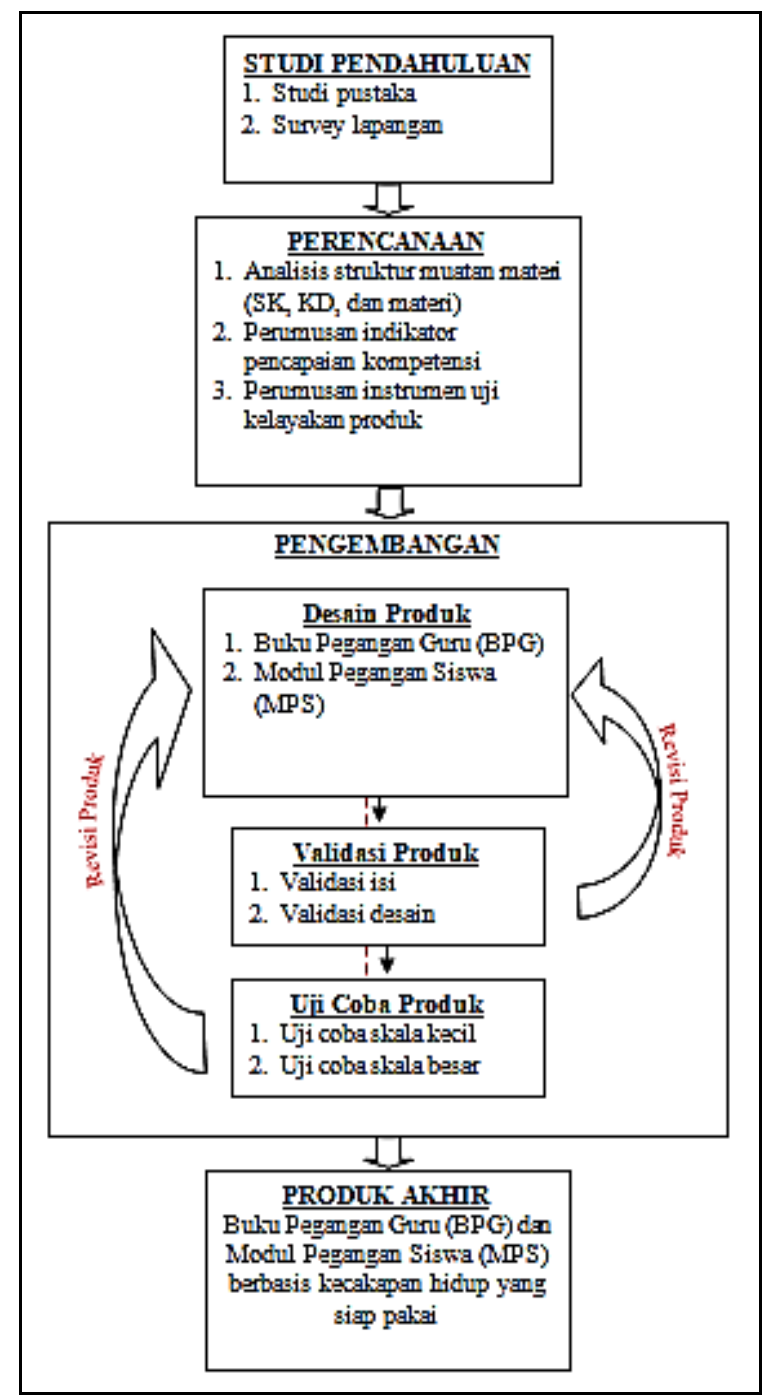

Gambar 1. Prosedur Pengembangan Model Borg \& Gall Modifikasi

Pengembangan yang dilakukan diawali dengan studi pendahuluan, dilanjutkan dengan perencanaan dan desain produk, uji coba awal dimana produk awal divalidasi oleh ahli materi dan ahli desain, dilanjutkan dengan uji coba produk yang terdiri dari uji coba lingkup kecil dan uji coba lingkup besar, revisi produk, dan terakhir yaitu produk berupa modul berbasis kecakapan hidup yang telah valid, praktis, menarik, dan efektif.

Produk dikategorikan valid apabila rata-rata persentasi angket yang diberikan kepada validator materi dan validator desain bernilai minimal $80 \%$. Produk dikategorikan praktis apablila rata-rata persentase angket kepraktisan yang diberikan kepada guru dan siswa bernilai minimal 80\%. Produk dikategorikan 
menarik apablila rata-rata persentase angket kemenarikan yang diberikan kepada siswa bernilai minimal 80 Bahan ajar dikatakan efektif jika $\geq 70 \%$ siswa memperoleh nilai tes $(E) \geq 70(\mathrm{KKM})$.

\section{HASIL PENELITIAN DAN PEMBAHASAN}

Setelah melakukan studi pendahuluan berupa studi pustaka (mengaji ruang lingkup bahan ajar, prosedur dan prinsip penyusunan modul, ruang lingkup pendidikan kecakapan hidup (life skill), hakikat pembelajaran matematika SD, teori belajar pada pembelajaran matematika SD, serta penelitian terdahulu yang relevan dengan pengembangan bahan ajar modul berbasis kecakapan hidup (life skill)) dan survey lapangan, diperoleh data siswa kelas VI kesulitan memahami pelajaran matematika khususnya materi Debit. Hal ini terbukti dengan nilai siswa dalam pokok bahasan ini rendah selama 3 tahun terakhir jika dibandingkan dengan pokok bahasan lainnya, yaitu sejak tahun ajaran 2015/2016 sampai dengan 2017/2018. Siswa sulit mengonversi antarsatuan Volume, menentukan hubungan antarsatuan Debit, dan menyelesaikan soal cerita yang berkaitan dengan Debit. Selain itu, dari tahun ke tahun guru belum pernah menggunakan bahan ajar lain selain buku ajar (Buku Paket Matematika untuk Kelas VI SD/MI) dan buku penunjang (LKS). Kemungkinan besar, hal ini juga merupakan salah satu penyebab rendahnya prestasi belajar siswa. Setelah dianalisis, bahan ajar yang digunakan guru hanya fokus membekali siswa untuk cakap akademik saja, serta materi yang disajikan menggunakan rumus-rumus abstrak yang hanya dapat dipahami oleh orang-orang dewasa tanpa adanya keterkaitan dengan kehidupan sehari-hari siswa.

Berdasarkan hasil studi pendahuluan, peneliti melakukan perencanaan produk yang akan dikembangkan. Dalam kegiatan perencanaan dilakukan analisis struktur muatan materi, perumusan indikator pencapaian kompetensi, dan perumusan uji kelayakan produk. Kompetensi Inti dan Kompetensi Dasar yang diambil adalah Kompetensi Inti yang sesuai dengan kurikulum yang digunakan SDN Curahsawo, yaitu Kompetensi Inti 2. Menggunakan Pengukuran Volume Perwaktu dalam Pemecahan Masalah, dan KD 2.1 Mengenal Satuan Debit, 2.2 Menyelesaikan Masalah yang Berkaitan dengan Debit. 
Indikator pencapaian kompetensi yang tercantum dalam kurikulum SDN Curahsawo yaitu; 1) Siswa memahami satuan Debit, 2) Siswa dapat menyelesaikan persoalan berkaitan dengan Debit. Sementara itu, direncanakan indikator pencapaian kompetensi yang berbeda dengan kurikulum SDN Curahsawo. Siswa kembali diingatkan mengenai satuan yang terlibat dalam satuan Debit yaitu satuan volume dan satuan waktu serta disesuaikan dengan tujuan pembuatan modul yaitu siswa dapat belajar secara mandiri dan dibekali dengan kecakapan personal, sosial, akademik, dan vokasional.

Selanjutnya, dilanjutkan pada tahap desain produk. Dalam desain produk, peneliti menyusun produk berupa Buku Pegangan Guru (BPG) dan Modul Pegangan Siswa (MPS). Produk ini disebut produk awal sebelum divalidasi dan direvisi.

Validasi Produk dilaksanakan setelah Modul berbasis kecakapan hidup materi Debit selesai disusun. Validasi Produk dilakukan untuk mengukur tingkat kevalidan modul berbasis kecakapan hidup $(\mathrm{Vm})$. Untuk mengukur tingkat kevalidan modul, perlu diukur tingkat kevalidan materi $(V i)$ dan desain $(V d)$. Berhubungan dengan hal tersebut, dilakukan validasi pada ahli materi dan ahli desain. Ahli materi diserahkan kepada Dr. Flavia Aurelia Hidajat, M.Pd. Ahli desain diserahkan kepada Shofia Hattarina, S. Pd., M. Pd. Tujuan Validasi Produk adalah untuk mengukur tingkat kelayakan modul yang akan diujicobakan kepada siswa. Berikut disajikan pada Gambar 2 dan Gambar 3 terkait hasil validasi ahli materi dan ahli desain.

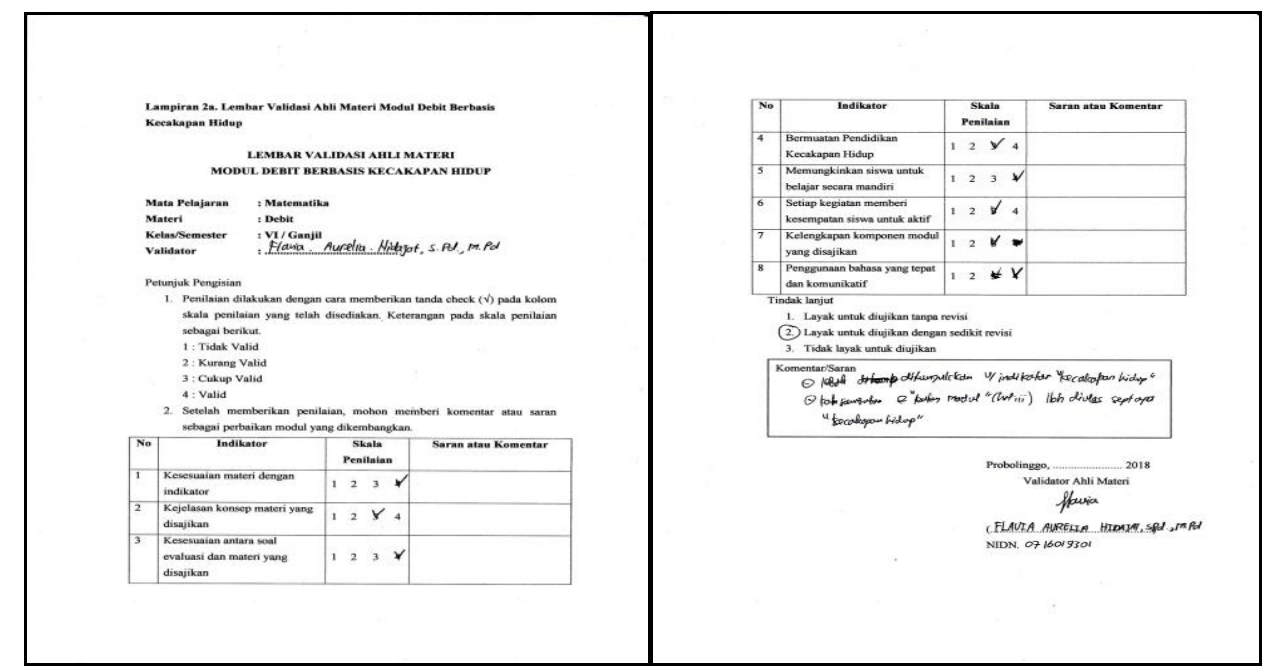

Gambar 2. Hasil Validasi Ahli Materi 


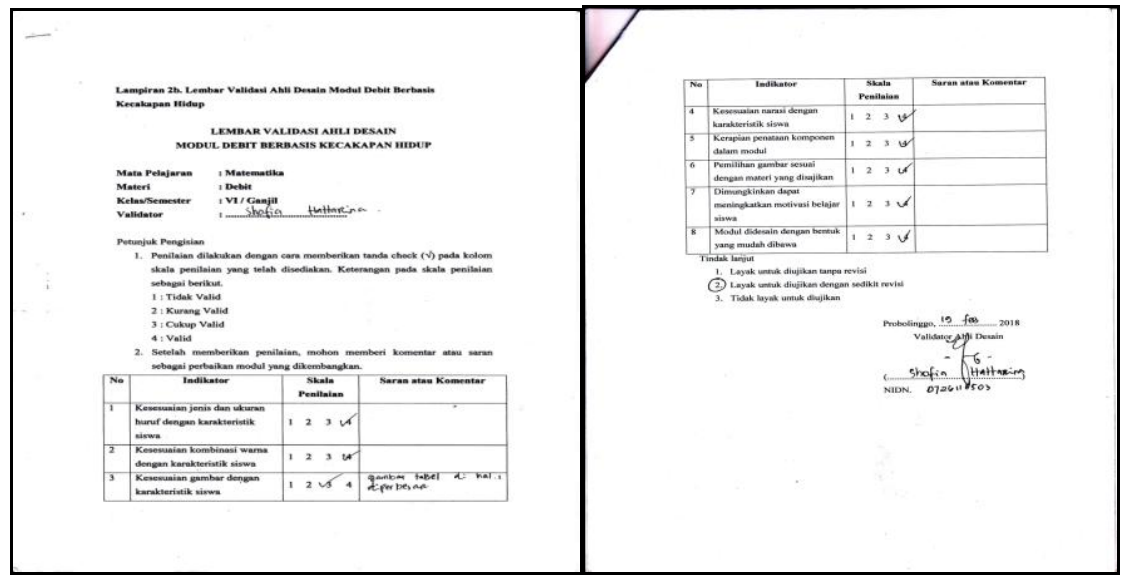

Gambar 3. Hasil Validasi Ahli Desain

Berdasarkan Gambar 2, validasi Ahli Materi dapat direkapitulasi dan ditampilkan dalam Tabel 1 berikut ini.

Tabel 1. Rekapitulasi Validasi Ahli Materi

\begin{tabular}{|c|c|c|c|}
\hline No & Indikator & Skor & Saran atau Komentar \\
\hline 1 & $\begin{array}{l}\text { Kesesuaian materi dengan } \\
\text { indikator }\end{array}$ & 4 & 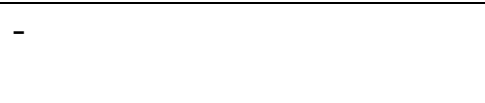 \\
\hline 2 & $\begin{array}{l}\text { Kejelasan konsep materi yang } \\
\text { disajikan }\end{array}$ & 3 & $\begin{array}{l}\text { Pada halaman } 3 \text {, siswa } \\
\text { diajak untuk mencari } \\
\text { hubungan secara mandiri }\end{array}$ \\
\hline 3 & $\begin{array}{l}\text { Kesesuaian antara soal evaluasi } \\
\text { dan materi yang disajikan }\end{array}$ & 4 & - \\
\hline 4 & $\begin{array}{l}\text { Kesesuaian kegiatan dengan } \\
\text { Pendidikan Kecakapan Hidup }\end{array}$ & 3 & $\begin{array}{l}\text { Lebih ditunjukkan } \\
\text { karakteristik kecakapan } \\
\text { hidupnya }\end{array}$ \\
\hline 5 & $\begin{array}{l}\text { Memungkinkan siswa untuk } \\
\text { belajar secara mandiri }\end{array}$ & 4 & - \\
\hline 6 & $\begin{array}{l}\text { Setiap kegiatan memberi } \\
\text { kesempatan siswa untuk aktif }\end{array}$ & 3 & - \\
\hline 7 & $\begin{array}{l}\text { Kelengkapan komponen modul } \\
\text { yang disajikan }\end{array}$ & 3 & $\begin{array}{l}\text { Dalam kata sambutan dan } \\
\text { tentang modul lebih diulas } \\
\text { seperti apa kecakapan hidup }\end{array}$ \\
\hline 8 & $\begin{array}{l}\text { Penggunaan bahasa yang tepat } \\
\text { dan komunikatif }\end{array}$ & 4 & - \\
\hline & Jumlah Skor Maksimal & 32 & \\
\hline & Jumlah Skor Perolehan & 28 & \\
\hline
\end{tabular}

Selanjutnya, Berdasarkan Gambar 3, validasi Ahli Desain dapat direkapitulasi dan ditampilkan dalam Tabel 2. 
Tabel 2. Rekapitulasi Validasi Ahli Desain

\begin{tabular}{|c|c|c|c|}
\hline No & Indikator & Skor & Saran atau Komentar \\
\hline 1 & $\begin{array}{l}\text { Kesesuaian jenis dan ukuran } \\
\text { huruf dengan karakteristik } \\
\text { siswa }\end{array}$ & 4 & - \\
\hline 2 & $\begin{array}{l}\text { Kesesuaian kombinasi warna } \\
\text { dengan karakteristik siswa }\end{array}$ & 4 & - \\
\hline 3 & $\begin{array}{l}\text { Kesesuaian gambar dengan } \\
\text { karakteristik siswa }\end{array}$ & 3 & $\begin{array}{c}\text { Gambar pada halaman } 1 \\
\text { diperbesar }\end{array}$ \\
\hline 4 & $\begin{array}{l}\text { Kesesuaian narasi dengan } \\
\text { karakteristik siswa }\end{array}$ & 4 & - \\
\hline 5 & $\begin{array}{l}\text { Kerapian penataan komponen } \\
\text { dalam modul }\end{array}$ & 4 & - \\
\hline 6 & $\begin{array}{l}\text { Pemilihan gambar sesuai } \\
\text { dengan materi yang disajikan }\end{array}$ & 4 & - \\
\hline 7 & $\begin{array}{l}\text { Dimungkinkan dapat } \\
\text { meningkatkan motivasi belajar } \\
\text { siswa }\end{array}$ & 4 & - \\
\hline \multirow[t]{3}{*}{8} & $\begin{array}{l}\text { Modul didesain dengan bentuk } \\
\text { yang mudah dibawa }\end{array}$ & 4 & - \\
\hline & Jumlah Skor Maksimal & 32 & \\
\hline & Jumlah Skor Perolehan & 31 & \\
\hline
\end{tabular}

Berdasarkan hasil validasi Ahli Materi, saran perbaikan tersebut disajikan pada Gambar 4, 5, 6, dan 7.

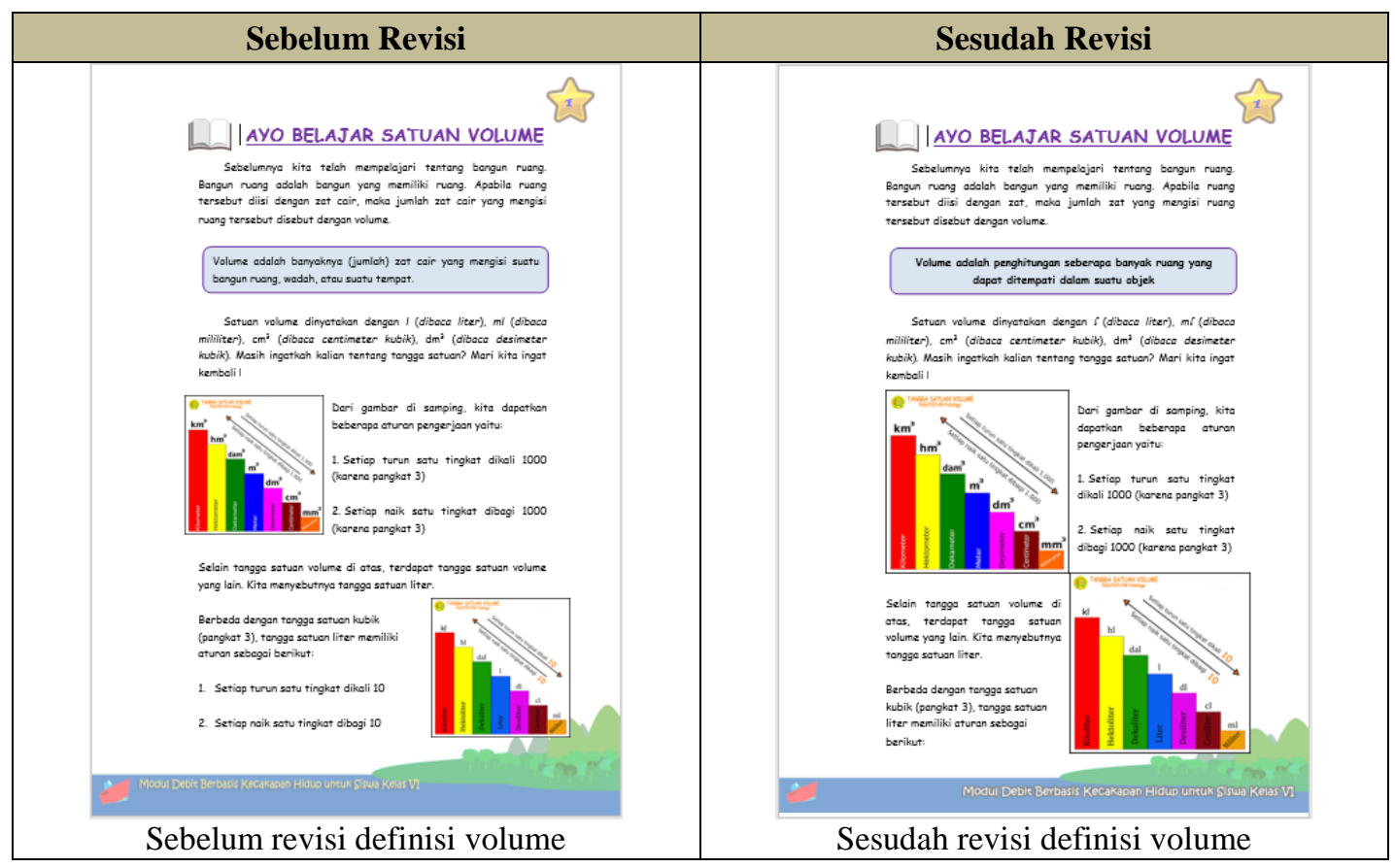

Gambar 4. Revisi Materi Definisi Volume 
Afib Rulyansah', Mardiyatus Sholihati ${ }^{2}$

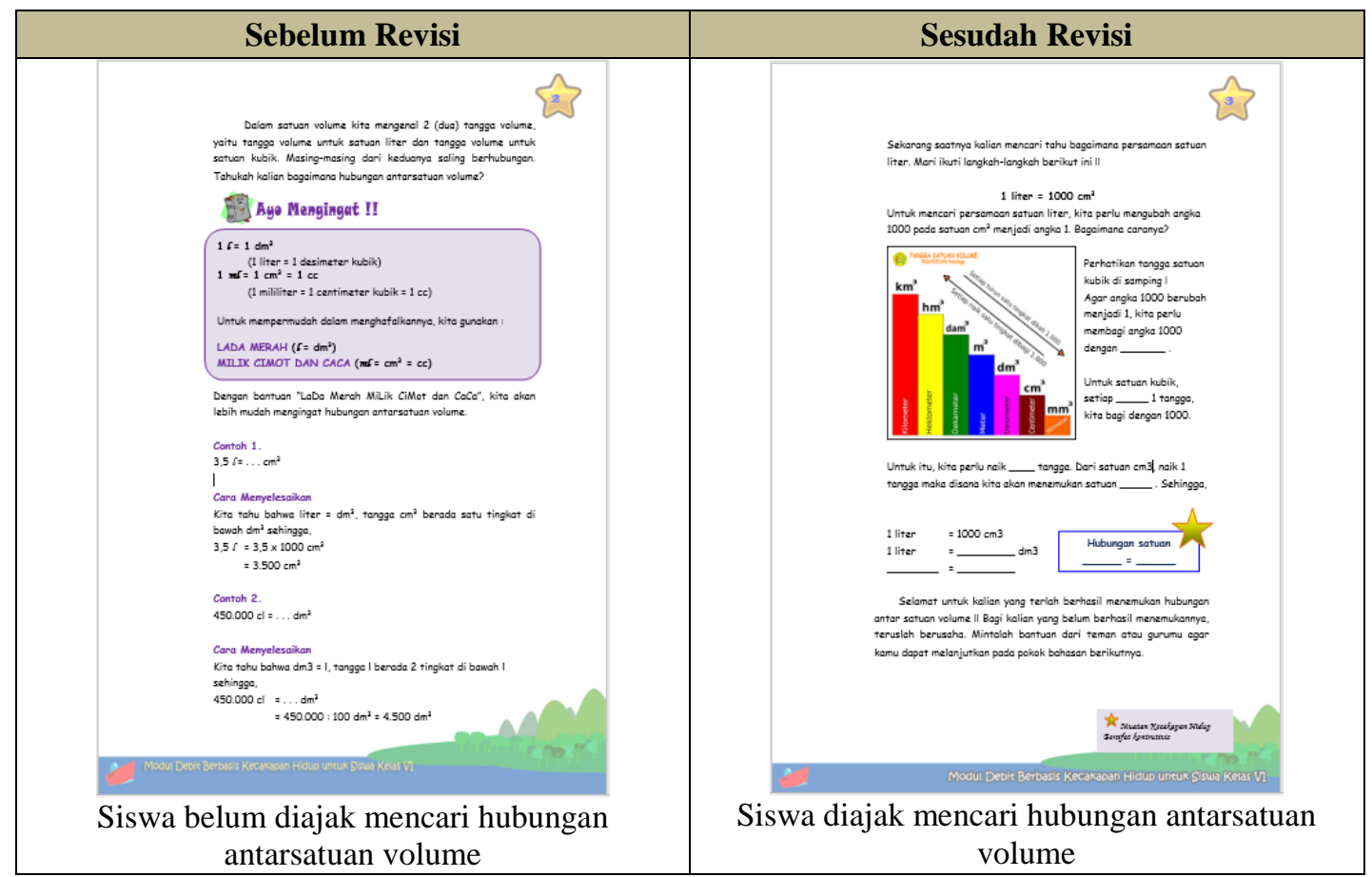

Gambar 5. Revisi Sebelum dan Sesudah Siswa Diajak Mencari Hubungan Antar Satuan Volume

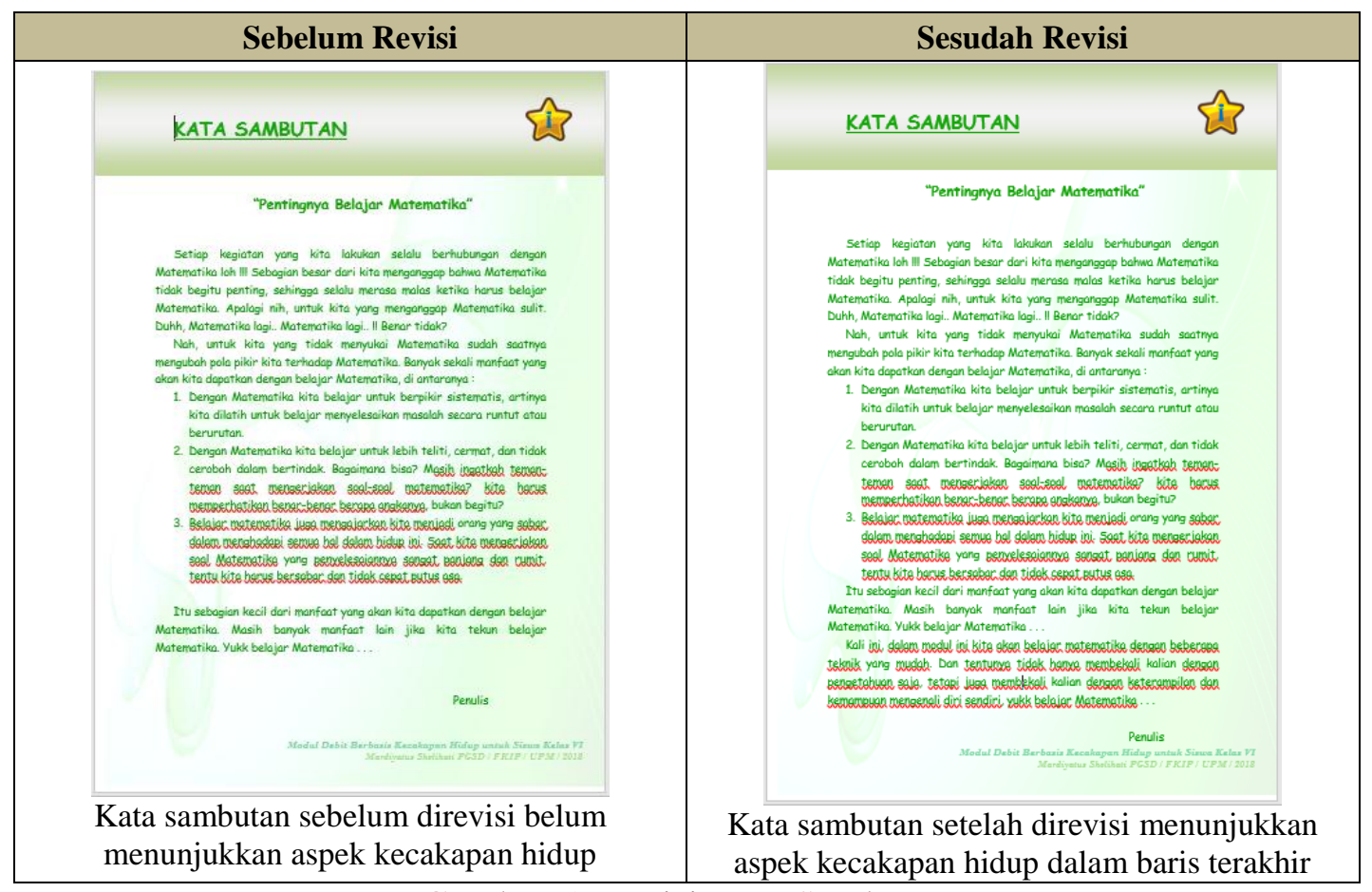

Gambar 5. Revisi Kata Sambutan 


\begin{tabular}{|c|c|}
\hline Sebelum Revisi & Sesudah Revisi \\
\hline TENTANG MODUL. & TENTANG MODUL. \\
\hline 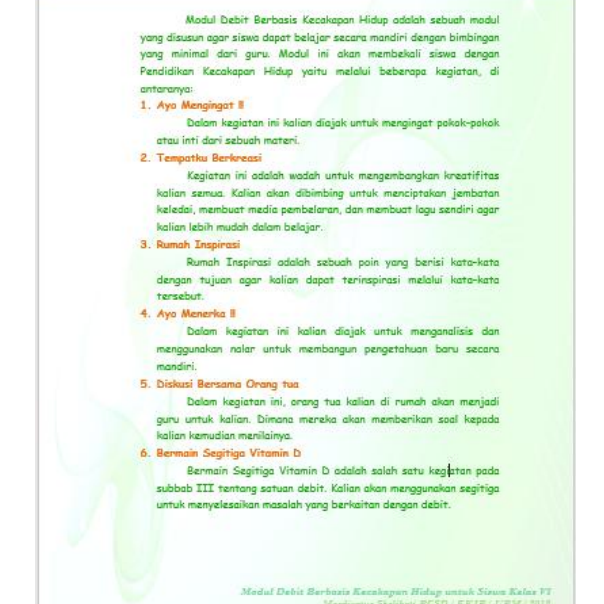 & 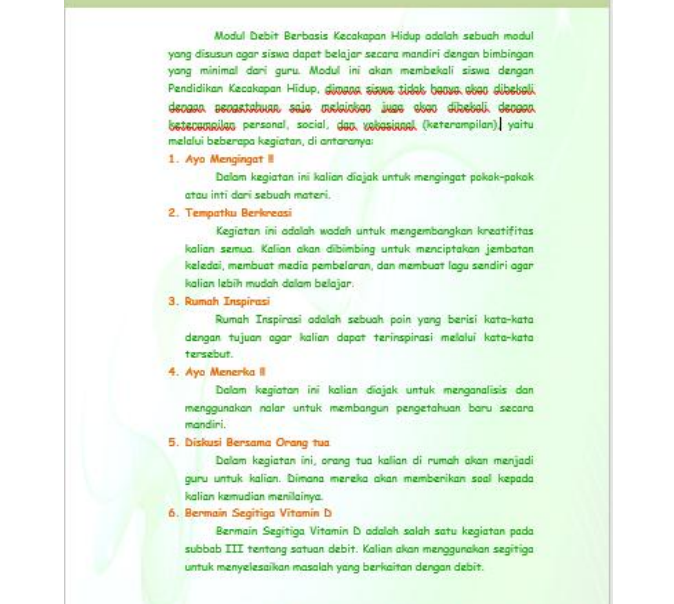 \\
\hline $\begin{array}{l}\text { Tentang modul sebelum direvisi belum } \\
\text { mengulas lebih banyak tentang kecakapan } \\
\text { hidup }\end{array}$ & $\begin{array}{l}\text { Tentang modul setelah direvisi lebih mengulas } \\
\text { tentang pendidikan kecakapan hidup }\end{array}$ \\
\hline
\end{tabular}

Gambar 7. Revisi Tentang Modul

Untuk selanjutnya, hasil validasi dari ahli desain disajikan pada Gambar 8 dan 9.

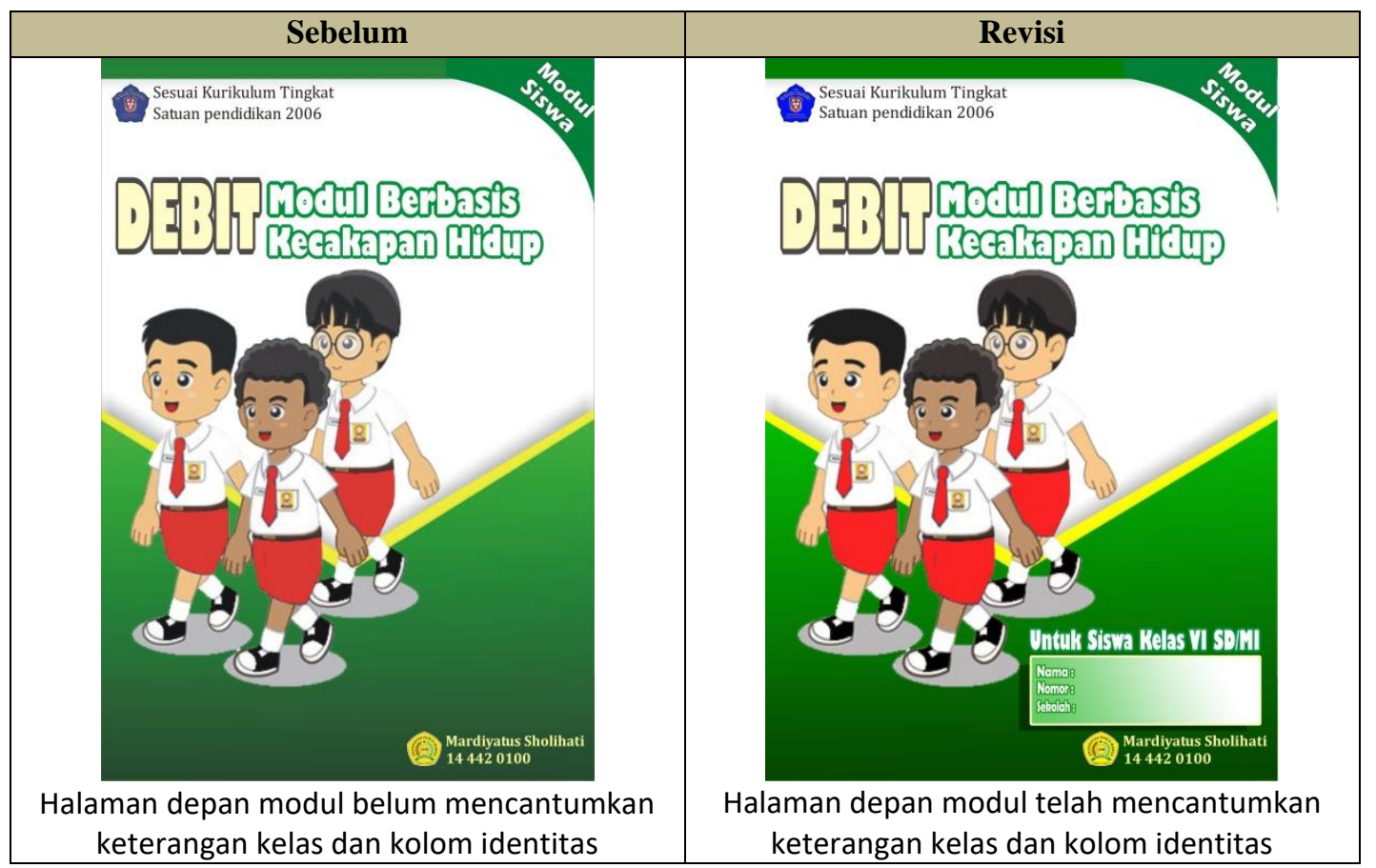

Gambar 8. Revisi Halaman Depan Modul 


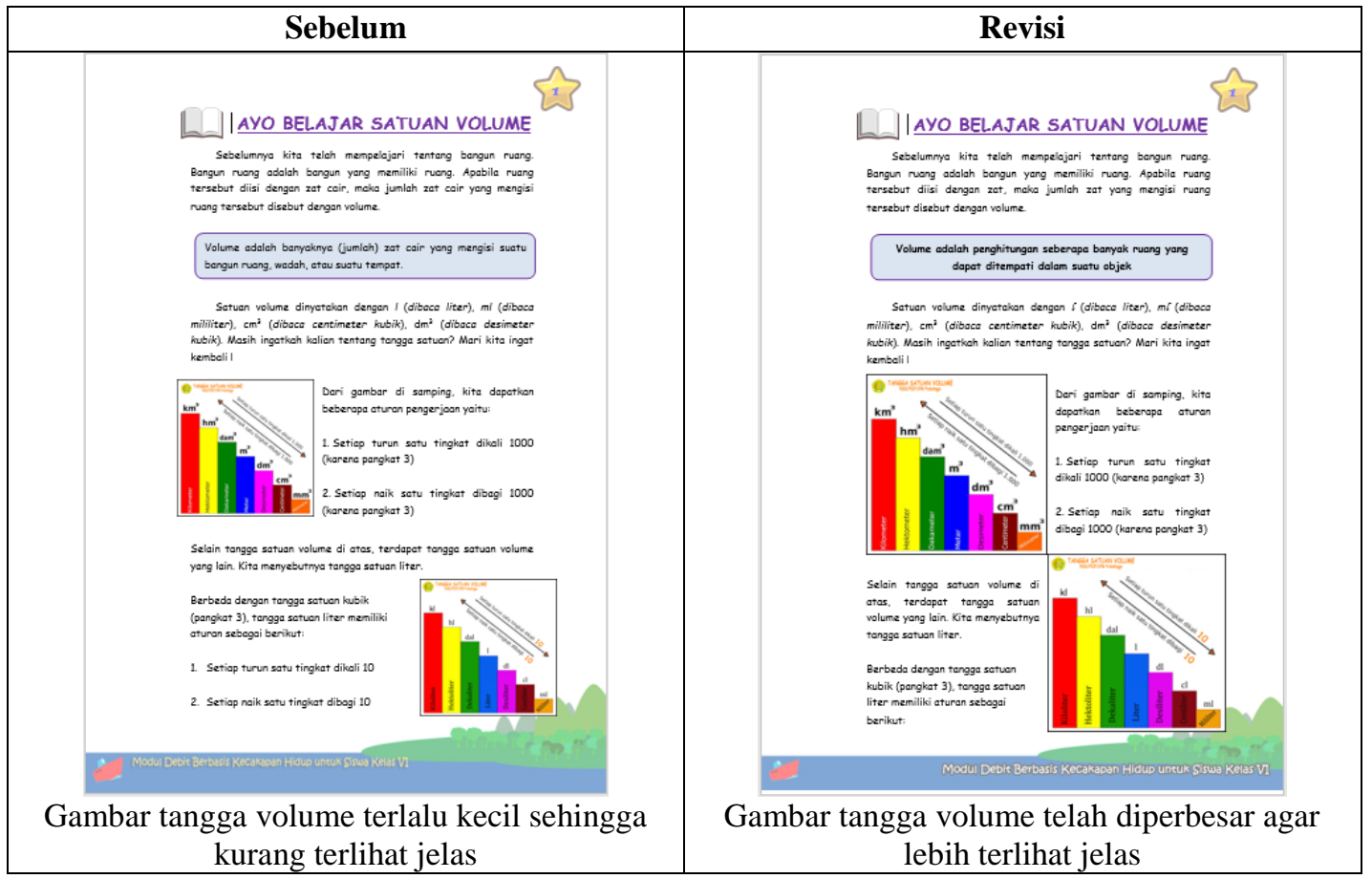

Gambar 9. Revisi Gambar Tangga

Hasil validasi ahli materi dan ahli desain dapat dianalisis mengenai tingkat kevalidan materi $(V i)$ dan desain $(V d)$, sehingga dapat ditemukan rata-rata untuk mengukur tingkat kevalidan modul Debit berbasis kecakapan hidup. Tingkat kevalidan materi modul Debit berbasis kecakapan hidup (Vi) mencapai 87,5\%. Tingkat kevalidan desain modul berbasis kecakapan hidup ( $V d)$ mencapai 96,8\% berada dalam kategori valid. Setelah didapat tingkat kevalidan materi $(V i)$ dan kevalidan desain $(V d)$, dilakukan pengambilan rata-rata untuk mendapatkan hasil tingkat kevalidan modul Debit berbasis kecakapan hidup $(\mathrm{Vm})$. Berikut hasil tingkat kevalidan modul Debit berbasis kecakapan hidup.

$$
\begin{aligned}
V m & =\frac{V i+V d}{2} \times 100 \% \\
V m & =\frac{87,5+96,8}{2} \times 100 \% \\
V m & =92,15 \%
\end{aligned}
$$

Berdasarkan perhitungan, tingkat kevalidan modul berbasis kecakapan hidup ( $\mathrm{Vm})$ mencapai $92,15 \%$.

Uji skala kecil dilakukan setelah modul Debit berbasis kecakapan hidup divalidasi oleh ahli pada Validasi Produk. Uji coba lingkup kecil ini dilakukan untuk mengukur tingkat kepraktisan $(P m)$, kemenarikan $(M)$ dan keefektifan 
modul Debit berbasis kecakapan hidup $(E)$ pada pelajaran Matematika kelas VI SDN Curahsawo Kecamatan Gending Kabupaten Probolinggo. Untuk mengukur tingkat kepraktisan modul $(P m)$, digunakan 2 angket yaitu angket kepraktisan untuk guru $(P g)$ dan angket kepraktisan untuk siswa $(P s)$. Sementara untuk mengukur tingkat kemenarikan modul, digunakan angket kemenarikan $(M)$ yang diberikan pada siswa. Angket kepraktisan dan kemenarikan diberikan diberikan kepada 6 siswa kelas VI SD Negeri Curahsawo yang berkapabilitas tinggi, sedang, dan rendah pelajaran matematika.

Berdasarkan rekapitulasi hasil angket kepraktisan dan kemenarikan pada uji coba lingkup kecil, dapat dianalisis mengenai angket kepraktisan $(P m)$ dan angket kemenarikan $(M)$ baik itu diisi oleh guru, siswa, maupun keduanya.

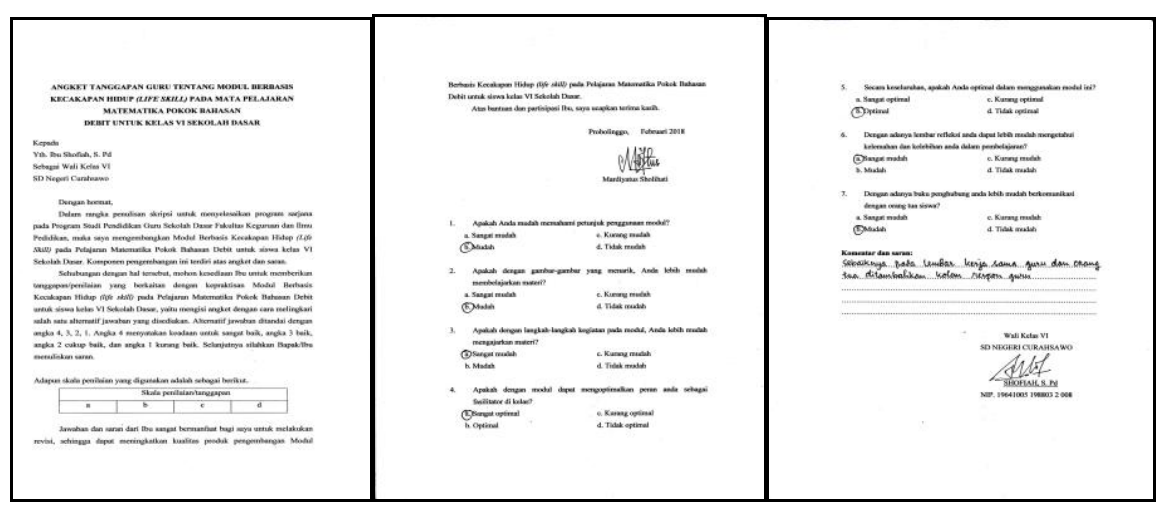

Gambar 10. Hasil Angket Kepraktisan Guru

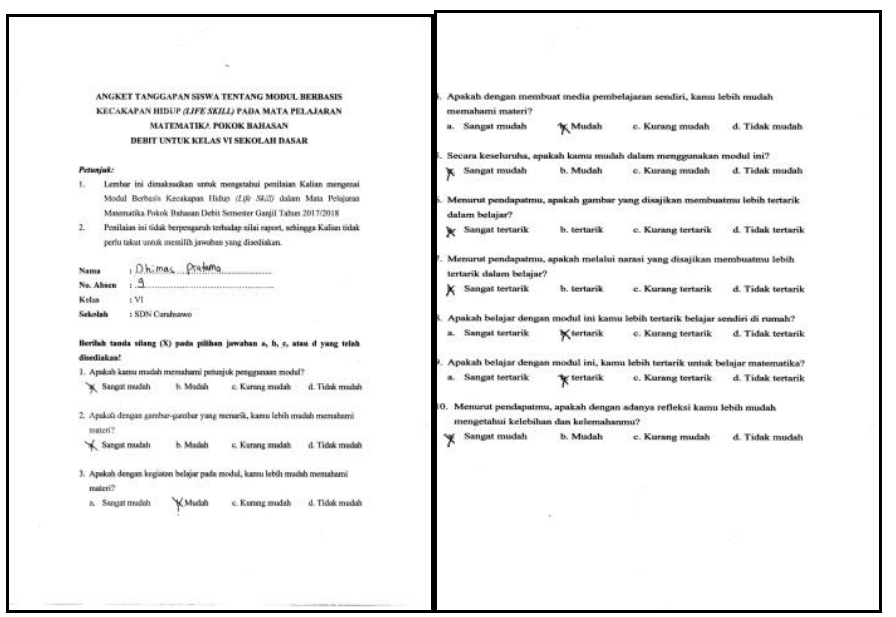

Gambar 11. Hasil Angket Kepraktisan dan Kemenarikan Siswa

Terlihat pada Gambar 10 dan Gambar 11 bahwa tingkat kepraktisan menurut guru $(P g)$ dan siswa $(P s)$ masing-masing mencapai prosentase 89,2\% dan 
87,5\%. Untuk mendapatkan tingkat kepraktisan secara umum atau keseluruhan, diambil rata-rata dari tingkat kepraktisan menurut guru $(P g)$ dan tingkat kepraktisan menurut siswa $(P s)$, sehingga diperoleh hasil tingkat kepraktisan modul Debit berbasis kecakapan hidup $(P m)$ sebagai berikut.

$$
\begin{aligned}
P m & =\frac{P_{g}+P_{s}}{2} \times 100 \% \\
P m & =\frac{89,2+87_{x} 5}{2} \times 100 \% \\
P m & =88,35 \%
\end{aligned}
$$

Berdasarkan penghitungan, tingkat kepraktisan modul Debit berbasis kecakapan hidup (Pm) mencapai 88,35\%. Sementara Tingkat kemenarikan modul Debit berbasis kecakapan hidup mencapai persentase 94,1\%. Pemberian gambargambar dan kombinasi warna yang disesuaikan dengan karakteristik siswa membuat siswa lebih tertarik dalam belajar.

Uji coba lingkup besar dilaksanakan setelah uji coba lingkup kecil dilakukan. Uji coba lingkup besar ini dilakukan untuk mengukur tingkat kepraktisan $(P m)$, kemenarikan $(M)$, dan keefektifan $(E)$ modul Debit berbasis kecakapan hidup. Angket kepraktisan $(P m)$ dan kemenarikan $(M)$ diberikan kepada siswa kelas VI SD Negeri Curahsawo yang berjumlah 24 siswa terdiri atas 7 laki-laki dan 18 perempuan. Sementara untuk mengukur tingkat keefektifan modul Debit berbasis kecakapan hidup $(E)$, peneliti menggunakan soal evaluasi berisi 15 soal uraian yang di dalamnya mencakup materi subbab 1 satuan volume, subbab 2 satuan waktu, dan subbab 3 satuan Debit.

Tingkat kepraktisan modul Debit berbasis kecakapan hidup yang dilakukan pada uji coba lingkup besar mencapai 89,5\% berada dalam kategori valid tanpa revisi. Begitu pula tingkat kemenarikan modul Debit berbasis kecakapan hidup yang dilakukan pada uji coba lingkup besar ini mencapai 92,5\% berada dalam kategori valid tanpa revisi.

Tingkat keefektifan modul Debit berbasis kecakapan hidup mencapai 83,3\%. Dari hasil tersebut terlihat bahwa sebanyak 20 siswa telah mendapatkan nilai di atas KKM, sedangkan 4 siswa lain belum mencapai KKM. Kriteria Ketuntasan Minimal (KKM) individu di kelas VI SD Negeri Curahsawo adalah 70, sedangkan untuk Kriteria Ketuntasan Minimal (KKM) klasikal adalah 70\%. 


\section{Pengembangan Modul Berbasis Kecakapan Hidup pada Pelajaran Matematika Sekolah Dasar}

Dari hasil tingkat keefektifan, KKM individu, dan klasikal, pembelajaran Matematika dalam materi Debit dapat dikatakan efektif.

Modul Debit Berbasis Kecakapan Hidup untuk Siswa Kelas VI disusun secara utuh yang didalamnya mencakup semua unsur modul, yaitu (1) rumusan tujuan pembelajaran, (2) petunjuk bagi guru yang terdapat dalam modul guru dan petunjuk bagi siswa yang terdapat dalam modul siswa, (3) lembar kegiatan siswa, (4) lembar evaluasi, (5) kunci jawaban dan pembahasan yang terdapat dalam modul guru, (6) lembar refleksi bagi guru dan siswa, (7) lembar kerjasama antara guru dan orang tua.

Dalam modul guru disajikan silabus pembelajaran yang telah disesuaikan dengan Program Semester (Promes) semester ganjil tahun 2017/2018. Di halaman berikutnya terdapat peta konsep yang berisi tentang pemetaan indikator dalam materi Debit , dimana dalam pokok bahasan ini terdapat 3 indikator untuk masingmasing subbab dengan 4 tujuan pembelajaran pada Subab I Satuan Volume dan masing-masing 5 tujuan pembelajaran pada Subab II Satuan Waktu dan Subab III Satuan Debit. Langkah-langkah kegiatan diuraikan secara detail dilengkapi dengan gambar pada modul siswa sehingga mempermudah guru dalam melaksanakan kegiatan pembelajaran. Langkah-langkah kegiatan juga dilengkapi dengan beberapa alternatif solusi dan catatan sehingga guru dapat memilih kegiatan yang sesuai diaplikasikan pada saat pembelajaran berlangsung. Penilaian disajikan dilengkapi dengan rubrik atau pedoman penilaian sehingga guru mudah dalam menilai siswa. Selain itu soal evaluasi dilengkapi dengan kunci jawaban dan pembahasan. Untuk jawaban terbuka dicantumkan beberapa alternatif jawaban yang benar apabila dikerjakan dengan langkah yang berbeda. Sementara untuk lembar buku penghubung atau rekapitulasi kerjasama antara guru dan siswa terdiri dari 5 kolom, yaitu kolom nomor, nama, perkembangan pada subab I, perkembangan pada subab II, perkembangan pada subab III, dan tindak lanjut. Lembar ini nantinya akan dijadikan acuan untuk guru dalam melaksanakan bimbingan konseling pada siswa.

Sementara untuk siswa, modul disajikan dengan bahasa lisan agar siswa seolah-olah merasa sedang diajar oleh seorang guru. Modul siswa terdiri dari 10 bagian. Bagian pertama adalah kata sambutan. Awalnya kata sambutan berisi 
ulasan tentang pentingnya belajar matematika. Dimana dalam lembar kata sambutan ini, siswa atau pengguna modul diajak untuk mengubah pola pikir terhadap matematika yang pada umumnya dianggap sebagai bidang studi yang sulit dan kurang menyenangkan. Setelah dilakukan revisi atas saran dari ahli materi, kata sambutan berisi ulasan tentang pentingnya belajar matematika dan uraian singkat tentang kecakapan hidup. Bagian kedua yaitu Isi modul ini. Bagian Isi Modul Ini merupakan lembar daftar isi. Tetapi, istilah isi modul ini dipilih atas dasar penyesuaian dengan karakteristik siswa. Bagian selanjutnya adalah Tentang modul. Bagian Tentang Modul fungsinya sama dengan lembar petunjuk penggunaan modul, dimana pada bagian ini siswa akan membaca beberapa kegiatan yang akan mereka lakukan selama kegiatan pembelajaran menggunakan bahan ajar modul berbasis kecakapan hidup (life skill).

Bagian yang keempat adalah mind map materi yang berisi tentang bagan materi yang akan dipelajari. Bagian yang kelima, keenam, dan ketujuh adalah Materi persubbab. Bagian ini berisi materi yang harus dipelajari siswa secara mandiri atau melalui bimbingan yang minim dari guru. Yang membedakan antara modul berbasis kecakapan hidup (life skill) dengan modul-modul lain yaitu modul ini dilengkapi dengan kegiatan-kegiatan dan materi Debit yang tidak hanya membekali siswa cakap akademik saja, melainkan juga cakap personal, sosial, dan vokasional.

Bagian yang kedelapan adalah Aku Siap Diuji. Bagian ini berisi tes berupa butir soal yang harus dijawab oleh siswa. Soal disajikan dalam tiga subbab sesuai dengan penyajian materi, dimana dalam masing-masing masing-masing subab terdiri dari lima butir soal uraian yang harus dijawab oleh siswa. Adapun penskoran untuk soal evaluasi telah dicantumkan dalam modul guru. Selanjutnya adalah Lembar refleksi diri. Bagian ini memungkinkan siswa untuk memiliki keterampilan personal, dimana siswa dapat mengenali kekuatan dan kelemahan diri sendiri, dan bagaimana cara mengatasi kelemahan yang dimiliki. Bagian yang terakhir adalah buku penghubung. Fungsi buku penghubung adalah sebagai salah satu media komunikasi pendidik wali murid agar tercipta komunikasi dua arah yang efisien. Guru dapat mengetahui perkembangan belajar siswa di rumah, orang tua juga dapat mengetahui perkembangan belajar anak di sekolah. Selain bagian 
internal tersebut, di bagian paling akhir peneliti membuat kantong media sebagai tempat menyimpan media yang telah dibuat oleh siswa, seperti jembatan keledai untuk satuan volume, lagu untuk mempermudah menghafal satuan waktu, dan media pembelajaran untuk materi Debit yang terbuat dari kain flanel.

Modul berbasis Kecakapan Hidup materi Debit ini juga memiliki kelemahan, yaitu kegiatan-kegiatan pada setiap subbab belum mengajak siswa untuk belajar melalui percobaan sehingga siswa belum dapat belajar dari pengalaman. Siswa belajar secara mandiri hanya melalui tulisan bukan kegiatan. Hal ini karena keterbatasan sarana serta prasarana di sekolah. Selain itu, dalam melaksanakan kegiatan pembelajaran, modul ini sifatnya lebih instruktif sehingga siswa tidak diberi kesempatan untuk berinisiatif memilih kegiatan sendiri. Akan tetapi secara keseluruhan, modul Debit berbasis kecakapan hidup ini telah valid, praktis, menarik, efisien, serta dapat meningkatkan prestasi siswa dalam materi Debit.

\section{SIMPULAN}

Penelitian dan pengembangan ini menghasilkan modul Debit berbasis kecakapan hidup ini telah valid, praktis, menarik, efisien, serta dapat meningkatkan prestasi siswa dalam materi Debit. Hasil validasi ahli materi mencapai $87,5 \%$ dan hasil validasi ahli media mencapai $96,8 \%$. Hasil rata-rata angket kepraktisan mencapai persentase $88,35 \%$ dan hasil angket kemenarikan siswa mencapai persentase $94,1 \%$ dalam uji coba lingkup kecil. Sementara untuk uji coba lingkup besar, tingkat kepraktisan modul mencapai 89,5\%, tingkat kemenarikan modul mencapai 92,5\%, dan hasil evaluasi belajar siswa menunjukkan 83,3\% tuntas belajar atau 31,3\% lebih tinggi dibandingkan pretest yaitu $52 \%$. Berdasarkan hasil tersebut, modul berbasis kecakapan hidup telah valid, praktis, menarik, dan efektif digunakan dalam pembelajaran Matematika kelas VI.

\section{DAFTAR PUSTAKA}

Borg, W. R., \& Gall, M. D. (1983). Education Research An Introduction (4 ed.). New York: Longman Inc. 
Hindun, I. 2005. Model Pengembangan Pendidikan Kecakapan Hidup (Life Skill) pada Sekolah Umum Tingkat Menengah di Kota Batu.. Jurnal Humanity 1(1), 29-35.

Majid, A. 2009. Perencanaan Pembelajaran: Mengembangkan Kompetensi Inti Guru. Bandung: PT Remaja Rosdakarya Offset.

Salahuddin, A. 2011. Filsafat Pendidikan. Bandung: CV. Pustaka Setia.

Sukmadinata, N. S. 2010. Metode Penelitian Pendidikan. Bandung: PT Remaja Rosdakarya Offset.

Supriatna, M. 2007. Pengembangan kecakapan hidup di sekolah. Dapat dilihat di https://s3.amazonaws.com/academia.edu.documents/33851702/09._PENG EMBANGAN_KECAKAPAN_HIDUP.pdf?AWSAccessKeyId=AKIAIWOW YYGZ2Y53UL3A\&Expires $=1544715714 \&$ Signature $=o Z X 784 Z A G K g B j f N$ VcloSHcoQm4c\%3D\&response-contentdisposition=inline\%3B\%20filename\%3DPENGEMBANGAN_KECAKAPA N_HIDUP_DI_SEKOLAH.pdf diakses tanggal 11 Agustus 2017.

Yasin, A. 2010. Mengukur Kompetensi Guru Melalui Standar Nasional Pendidikan.

Dapat dilihat di http://mebermutu.org/media.php? module $=$ detailreferensi\&id=54 diakses tanggal 10 Agustus 2017. 